\title{
APSA's 2012 Organized Sections Awards Presented
}

Th $\mathrm{n}$ addition to the APSA awards (see full listing and citations in the Gazette, this issue) the following recognitions were announced by the APSA Organized Sections.

SECTION 1. FEDERALISM AND

INTERGOVERNMENTAL RELATIONS Martha Derthick Book Award

Presented to the author of a book published at least ten years ago that has made a lasting contribution to the study of federalism and intergovernmental relations Award Committee: J. Mitchell Pickerill, Northern Illinois University (Chair); Marc Landy, Boston College; Anna O. Law, CUNY-Brooklyn College

Recipient: Donald H. Haider, Northwestern University

Title: When Governments Come to Washington: Governors, Mayors, and Intergovernmental Lobbying (1974), Free Press

\section{Deil S. Wright Best Paper Award}

Presented to the author of the best paper on federalism and intergovernmental relations presented at the 2011 APSA Annual Meeting

Award Committee: Kathleen Hale, Auburn University (Chair); Alec Ewald, University of Vermont; Sonja Walti, American University

Recipients: Charles R. Hankla, Georgia State University; Eunice Heredia-Ortiz, Development Alternatives, Inc.; Jorge Martinez-Vazquez, Georgia State University; Raul Ponce-Rodriguez, Universidad Autonoma de Ciudad Juarez

Title: "Rethinking the Political Economy of Decentralization: How Democracy and Political PartiesShape the Provision of Local Public Goods"

\section{Distinguished Scholar Award}

Recognizes a lifetime of contributions to the study of federalism and intergovernmental relations

Award Committee: J. Edwin Benton, University of South Florida (Chair); Jenna Bednar, University of Michigan; Jacob T. Levy, McGill University

Recipient: Barry R. Weingast, Stanford University

\section{SECTION 2. LAW AND COURTS Best Conference Paper Award}

For the best paper on law and courts presented at the 2011 annual meetings of the American, International, and regional political science associations

Award Committee: Jonathan P. Kastellec, Princeton University; J. Mitchell Pickerill, Northern Illinois University; Lee D. Walker, University of South Carolina

Recipient: Quinn W. Mulroy, Syracuse University

Title: "Enforcing Rights Protections: The Regulatory Power of Private Litigation and the Equal Employment Opportunity Commission"

\section{Best Graduate Student Paper Award}

For the best paper on law and courts written by a graduate student

Recipient: Maya Sen, University of Rochester

Title: "Is Justice Really Blind: Race and Appellate Review in U.S. Courts"

\section{Best Journal Article Award}

Recognizes the best journal article on law and courts written by a political scientist and published during the previous calendar year

Award Committee: Scott A. Comparato, Southern Illinois University, Carbondale; Alison Gash, University of Oregon Recipients: Bryan T. Calvin, Tarrant County College; Paul M. Collins, Jr., University of North Texas; Pamela C. Corley, Southern Methodist University

Title: "Lower Court Influence on U.S. Supreme Court Opinion Content" (January 2011, The Journal of Politics)

\section{Herman Pritchett Award}

For the best book on law and courts written by a political scientist and published the previous year

Award Committee: Charles Anthony Smith, University of California, Irvine; Joseph D. Ura, Texas A\&M University; Eric Waltenburg, Purdue University

Recipient: Matthew E.K. Hall, Saint Louis University

Title: The Nature of Supreme Court Power, Cambridge University Press

\section{Lifetime Achievement Award}

Honors a distinguished career of scholarly achievement and service to the law and courts field

Award Committee: Lori J. Hausegger, Boise State University; John C. Kilwein, West Virginia University; Susan E. Lawrence, Rutgers University; Jeffrey Staton, Emory University; Mary L. Volcansek, Texas Christian University

Recipient: Robert A. Kagan, University of California, Berkeley

\section{Lasting Contribution Award}

For a book or journal article, 10 years or older, that has made a lasting impression on the field of law and courts

Award Committee:John Winkle, III (Chair); Christina L. Boyd, University at Buffalo, SUNY; Marcus E. Hendershot, University of Florida; Amy L. Steigerwalt, Georgia State University; Steven M. Teles, Johns Hopkins University; Justin J. Wert, University of Oklahoma

Recipient: R. Shep Melnick, Boston College Title: Between the Lines: Interpreting Welfare Rights (1994), Brookings Institution Press

\section{Law and Courts Service Award}

Recognizes service "to" the Section in the literal sense, as in service on committees and in leadership positions, as well as service "within" the Section, as in service to the profession within the field of law and courts in the form of archiving data, promoting infrastructures, represent the media, etc.

Award Committee: Tom Clark, Emory University; James L. Gibson, Washington University, St. Louis; David S. Law, Washington University, St. Louis; Julie L. Novkov, SUNY, University at Albany; Todd C. Peppers, Roanoke College

Recipient: Howard Gillman, University of Southern California

\section{Teaching and Mentoring Award}

Recognizes innovative teaching and instructional methods and materials in law and courts

Award Committee: Andreas Broscheid, James Madison University; Rebecca Wood Gill, University of Nevada, Las Vegas; Matthew C. Ingram, SUNY, University at Albany; Timothy R. Johnson, University of Minnesota; Anna R. Kirkland, University of Michigan, Ann Arbor

Recipient: Wendy L. Martinek, SUNY, Binghamton University 
SECTION 3. LEGISLATIVE STUDIES Alan Rosenthal Prize

For the best book or article in legislative studies written by a junior scholar that has potential value to legislative practitioners Award Committee: Kristina Miler, University of Maryland (Chair); Gail McElroy, Trinity College, Dublin; Keith E. Hamm, Rice University

Recipient: Vineeta Yadav, Pennsylvania State University

Title: Political Parties, Business Groups, and Corruption in Developing Countries, Oxford University Press

\section{Carl Albert Award}

For the best doctoral dissertation in the area of legislative studies. Topics may be national or subnational in focus-on Congress, parliaments, state legislatures, or other representative bodies.

Award Committee: Chris Den Hartog, California Polytechnic State University, San Luis Obispo (Chair); Kathryn C. Lavelle, Case Western Reserve University; Amber Wichowsky, Marquette University Recipient: James M. Curry, University of Utah

Title: "Information Control: Leadership Power in the U.S. House of Representatives" (University of Maryland)

\section{CQ Press Award}

For the best paper on legislative studies that was presented at the 2011 APSA Annual Meeting

Award Committee: Sean M. Theriault, University of Texas, Austin (Chair); Matthew Gabel, Washington University, St. Louis; Kristin Kanthak, University of Pittsburgh Recipients: Michael C. Brady, Denison University; Eric Gonzalez Juenke, Michigan State University;

Daniel J. Lee, Michigan State University Title: "An Indelible Imprint? Assessing the Evolution of Racial Politics in Shaping Conflict in Congress during the Civil Rights Era"

\section{Jewell-Loewenberg Award}

For best article in the Legislative Studies Quarterly in the previous year (2011) Award Committee: Jeremy Clayne Pope, Brigham Young University (Chair); Christopher J. Kam, University of British Columbia; Steven S. Smith, Washington University

Recipients: Rene Lindstadt, University of Essex; Jonathan B. Slapin, University of
Houston; Ryan J. Vander Wielen, Temple University

Title: "Balancing Competing Demands: Position Taking and Election Proximity and the European Parliament." (Legislative Studies Quarterly 36, February 2011, 37-70)

\section{Richard F. Fenno Prize}

For the best book in legislative studies published in 2011

Award Committee: Gregory Koger, University of Miami (Chair); Brian F. Crisp, Washington University, St. Louis; Cherie Maestas, Florida State University Recipients: Lanny W. Martin, Rice University; Georg Vanberg, University of North Carolina, Chapel Hill

Title: Parliaments and Coalitions: The Role of Legislative Institutions in Multiparty Governance, Oxford University Press

\section{SECTION 4. PUBLIC POLICY}

Aaron Wildavsky Enduring Contribution Award

For the best book or article published in the general area of public policy during the past 20 plus years

Award Committee: Elaine B. Sharp, University of Kansas (Chair); Thomas L. Gais, SUNY, University at Albany; Todd Swanstrom, University of Missouri, St. Louis

Recipient: Lester M. Salamon, Johns Hopkins University

Title: Partners in Public Service: Government-Nonprofit Relations in the Modern Welfare State (1995), Johns Hopkins University Press

\section{Best Poster on Public Policy Award}

For the best paper or poster presented at the poster session at the previous APSA Annual Meeting

Award Committee: Michael E. Kraft, University of Wisconsin, Green Bay (Chair); Ryane McAuliffe Straus, College of Saint Rose; Linda A. White, University of Toronto Recipient: Jake Haselswerdt, George Washington University

Title: "Death and Tax Breaks: Comparing the Survival Rates of Tax Expenditures and Direct Spending Programs"

\section{Best Public Policy Paper}

For the best paper on public policy given at the previous APSA Annual Meeting Award Committee: Lisa Garcia Bedolla, University of California, Berkeley (Chair); Scott W. Allard, University of Chicago; Neal Woods, University of South Carolina
Recipient: Daniel P. Aldrich, Purdue University

Title: "Social, Not Physical, Infrastructure: The Critical Role of Civil Society in Disaster Recovery"

\section{Best Paper in Comparative Public Policy}

Recognizes an article of particular distinction published in the area of comparative public policy, awarded in collaboration with the International Comparative Policy Analysis Forum/Journal of Comparative Policy Analysis

Award Committee: Meghna Sabharwal, University of Texas at Dallas (Chair); Frank R. Baumgartner, University of North Carolina, Chapel Hill; Alan M. Jacobs, University of British Columbia; David LeviFaur, Hebrew University

Recipients: Claire Annesley, University of Manchester; Isabelle Engeli, University of Geneva; Francesca Gains, University of Manchester

Title: "The Profile of Gender Equality Issue Attention in Western Europe"

\section{Excellence in Mentoring Award}

To recognize sustained efforts by a senior scholars to encourage and facilitate the career of emerging political scientists in the field of public policy

Award Committee: Doug Imig, University of Memphis (Chair); Khalilah L. BrownDean, Quinnipiac University; Patricia Strach, SUNY, University at Albany Recipient:John F. Witte, University of Wisconsin, Madison

\section{Theodore Lowi Award}

Recognizes an article of particular distinction published at any time in Policy Studies Journal

Award Committee: Sarah B. Pralle, Syracuse University (Chair); Susan L. Moffitt, Brown University; Carolyn Hughes Tuohy, University of Toronto

Recipients: Ashley E. Jochim, University of Washington; Peter J. May, University of Washington; Joshua Sapotichne, Michigan State University

Title: "Constructing Homeland Security: An Anemic Policy Regime" (Policy Studies Journal, 2011, 39(2): 285-307)

\section{SECTION 5. POLITICAL ORGANIZA- TIONS AND PARTIES}

\section{Emerging Scholars Award}

Awarded to a scholar who has received his or her $\mathrm{PhD}$ within the last 7 years and 
whose career to date demonstrates unusual promise

Award Committee: Frances E. Lee, University of Maryland (Chair); Raymond J. La Raja, University of Massachusetts, Amherst; Kyle L. Saunders, Colorado State University

Recipient: Daniel Galvin, Northwestern University

\section{Jack Walker Award}

Honors an article published in the last two calendar years that makes an outstanding contribution to research and scholarship on political organizations and parties Award Committee: Robert G. Boatright, Clark University (Chair); Hans Noel, Georgetown University; Kathryn Pearson, University of Minnesota

Recipients: Thomas M. Carsey, University of North Carolina, Chapel Hill; Rosalyn Cooperman, University of Mary Washington; John C. Green, University of Akron; Richard Herrera, Arizona State University; Geoffrey C. Layman, University of Notre Dame

Title: "Activists and Conflict Extension in American Party Politics" (American Political Science Review, 104(2))

\section{Leon Epstein Book Award of Political Organizations and Parties Section}

Honors a book published in the last two calendar years that makes an outstanding contribution to research and scholarship on political organizations and parties

Award Committee: Mark D. Brewer, University of Maine (Chair); Seth E. Masket, University of Denver; Zeynep Somer-Topcu, Vanderbilt University

Co-recipient: Daniel P. Klinghard, College of Holy Cross

Title: The Nationalization of American Political Parties, 1880-1896, Cambridge University Press

Co-recipient: Monika Nalepa, Princeton University

Title: Skeletons in the Closet: Transitional Justice in Post-Communist Europe, Cambridge University Press

\section{POP/Party Politics Award}

Honors the best paper presented on a POP panel at the preceding APSA Annual Meeting

Award Committee: Eric S. Heberlig, University of North Carolina, Charlotte (Chair); Michael M. Franz, Bowdoin College; Richard M. Skinner, Rollins College

Recipient: William G. Mayer, Northeastern
University

Title: "Theory Meets Practice: The Presidential Selection Process in the First Federal Election, 1788-89"

\section{Samuel Eldersveld Career Achieve- ment Lifetime Award}

To honor a scholar whose lifetime professional work has made an outstanding contribution to the field

Award Committee: Marjorie R. Hershey, Indiana University, Bloomington (Chair); Bruce A. Larson, Gettysburg College; Sean M. Theriault, University of Texas, Austin Recipient: Barbara Sinclair, University of California, Los Angeles

SECTION 6. PUBLIC

ADMINISTRATION

\section{Herbert Kaufman Award}

For the best paper presented on a panel sponsored by the Public Administration section at the 2011 APSA Annual Meeting Award Committee: Laurence J. O'Toole, University of Georgia (Chair); Kelly M. LeRoux, University of Illinois, Chicago; Katherine C. Naff, San Francisco State University

Recipients: Anthony Michael Bertelli, University of Southern California; Jennifer Connolly, University of Southern California; David Gastwirth, University of Southern California; Dyana P. Mason, University of Southern California

Title: "The Statistical Measurement of Accountability Constructs in American Governance"

\section{Herbert A. Simon Best Book Award}

The Herbert A. Simon Book Award for the best book published in the last 3 to 5 years that has made a significant contribution to public administration scholarship Award Committee: Kenneth J. Meier, Texas A\&M University (Chair); Julie Dolan, Macalester College; Hal G. Rainey, University of Georgia

Recipient: Donald P. Moynihan, University of Wisconsin, Madison

Title: The Dynamics of Performance Management (2008), Georgetown University Press

Volcker Junior Scholar Research Grant Awarded to a junior scholar researching public administration issues affecting governance in the United States and abroad Award Committee: Jerrell D. Coggburn, North Carolina State University; Sharon H. Mastracci, University of Illinois, Chicago; William G. Resh, Indiana University,
Bloomington

Recipient: Aroon P. Manoharan, Kent State University

Title: "Determinants of the Stages of County E-Government in the United States"

SECTION 8. REPRESENTATION AND ELECTORAL SYSTEMS

\section{George H. Hallet Award}

For a book, at least 10 years old, that has made a lasting contribution to the literature on representation and electoral systems

Award Committee: Kathleen Bawn, University of California, Los Angeles; Michael B. Berkman, Pennsylvania State University; Michael D. McDonald, SUNY, Binghamton Recipient: William H. Riker (deceased) Title: Liberalism Against Populism: A Confrontation Between the Theory of Democracy and the Theory of Social Choice

\section{Lawrence Longley Award}

For the best article on representation and electoral systems published in the previous year

Award Committee: Orit Kedar, Hebrew University of Jerusalem (Chair); Marisa Abrajano, University of California, San Diego; Susan Dayton Hyde, Yale University Recipients: Ernesto F. Calvo, University of Maryland; Timothy Hellwig, Indiana University, Bloomington

Title: "Centripetal and Centrifugal Incentives under Different Electoral Systems," American Journal of Political Science

\section{Leon Weaver Award}

The Leon Weaver Award given for the best paper presented at a panel sponsored by the Representation and Electoral Systems Division

Award Committee: Michelle M. TaylorRobinson, Texas A\&M University (Chair); Mark P. Jones, Rice University; Heather Stoll, University of California, Santa Barbara

Recipients: Russell J. Dalton, University of California, Irvine; David M. Farrell, University College Dublin, Belfield; Ian McAllister, Australian National University Title: "The Dynamics of Democratic Representation: How Democracy Works"

\section{SECTION 9. PRESIDENCY RESEARCH George C. Edwards III Best Dissertation}

For the best dissertation in presidency research completed and accepted during the 2010 or 2011 calendar year 
Award Committee: Katherine TenPass, University of Pennsylvania; Kenneth Mayer, University of Wisconsin; Jose Villalobos, University of Texas, El Paso

Recipient: William G. Resh, Indiana University, Bloomington

Title: "Rethinking the Administrative Presidency: Trust, Intellectual Capital, and Appointee-Careerist Relations" (American University)

\section{Founders PhD Scholar Best Paper Award}

For the best paper presented by a graduate student at either the preceding year's APSA Annual Meeting or at any of the regional meetings in 2011-2012

Award Committee: Nigel Bowles, University of Oxford; Victoria A. Farrar-Myers, University of Texas, Arlington; Paul J. Quirk, University of British Columbia; B. Dan Wood, Texas A\&M University

Recipient: Brendan J. Doherty, United States Naval Academy

Title: "The President as Party-Builder-inChief: Presidential Fund-raising, 19772011"

\section{Neustadt Award for the Best Book on the Presidency}

For the best book on the U.S. presidency published during the previous year Award Committee: Matthew J. Dickinson, Middlebury College (Chair); Julia Rezazadeh Azari, Marquette University; Lara Michelle Brown, Villanova University; Janet M. Martin, Bowdoin College; James P. Pfiffner, George Mason University Recipient: Michael J. Korzi, Towson University

Title: Presidential Term Limits in American History, Texas A\&M University Press

\section{Best Undergraduate Paper Award}

The best undergraduate paper completed in the academic year 2010-2011

Award Committee: David Yalof, University of Connecticut; Larry Berman, Georgia State University; Shirley Warshaw, Gettysburg College; Richard Holtzman, Bryant University

Recipient: Andrew Keene, United States Naval Academy

Title: "Exploration of Ticket Splitting: The Battleground State Effect"

SECTION 10. POLITICAL

\section{METHODOLOGY}

\section{Career Achievement Award}

Honors an outstanding career of intellectual accomplishment and service to the profession in political methodology

Award Committee: Jacob Bowers, University of Illinois at Urbana-Champaign; Janet M. Box-Steffensmeier, Ohio State University; Nancy Burns, University of Michigan; Tse-min Lin, University of Texas, Austin; James A. Stimson, University of North Carolina, Chapel Hill

Recipient: Henry E. Brady, University of California, Berkeley

\section{Emerging Scholar Award}

Honors a young researcher, within 10 years of his or her degree, who is making notable contributions to the field of political methodology

Award Committee: Wendy K. Tam Cho, University of Illinois at Urbana-Champaign; Simon D. Jackman, Stanford University; Jeffrey B. Lewis, University of California, Los Angeles; Kevin M. Quinn, University of California, Berkeley

Recipient: Jacob Bowers, University of Illinois at Urbana-Champaign

\section{Harold F. Gosnell Prize}

For the best work in political methodology presented at any political science conference during the preceding year

Award Committee: Kenneth W. Kollman, University of Michigan, Ann Arbor; Matthew Lebo, SUNY, Stony Brook University; Betsy Sinclair, University of Chicago Recipients: Thomas Gschwend, Universität Mannheim; James Lo, University of Mannheim; Sven-Oliver Proksch, University of Mannheim

Title: "A Common Left-Right Scale for Voters and Parties in Europe"

\section{John T. Williams Best Dissertation Award}

For the best dissertation proposal in the area of political methodology

Award Committee: Michael P. Colaresi, Michigan State University; Jonathan Nagler, New York University; Guy D. Whitten, Texas A\&M University

Recipient: Adriana Crespo-Tenorio, Washington University, St. Louis

Title: "Three Papers on the Political Consequences of Oil Price Volatility"

\section{Statistical Software Award}

Recognizes individual(s) for developing statistical software that makes a significant research contribution

Award Committee: Micah Altman, Massachusetts Institute of Technology; Kosuke Imai, Princeton University; Andrew D. Martin, Washington University; Curtis S. Signorino, University of Rochester; Arthur Spirling, Harvard University

Recipients: Walter R. Mebane, Jr., University of Michigan, Ann Arbor; Jasjeet Singh Sekhon, University of California, Berkeley Title: "genoud: Genetic Optimization using Derivatives"

\section{Warren Miller Article Award}

For the best article in Political Analysis in the previous year

Award Committee: Kosuke Imai, Princeton University; Burt L. Monroe, Pennsylvania State University; Gregory J. Wawro, Columbia University; B. Dan Wood, Texas A\&M University

Recipients: Devin Caughey, University of California, Berkeley; Jasjeet Singh Sekhon, University of California, Berkeley

Title: Elections and the Regression-Discontinuity Design: Lessons from Close U.S. House Races, 1942-2008 (Political Analysis, 19(4): $385-408)$.

\section{Political Methodology Poster Award}

For the best poster presented at the annual summer Political Methodology Meeting Award Committee: Patrick T. Brandt, University of Texas at Dallas; Robert S. Erikson, Columbia University; Stephen R. Haptonstahl, Institute for Physical Sciences, Inc.; Drew Linzer, Emory University; Walter R. Mebane, Jr., University of Michigan Recipient: Brenton Kenkel, University of Rochester

Title: "Bounds for Logistic Regression Coefficients with Nonignorable Missing Outcomes"

SECTION 11. RELIGION AND POLITICS

Aaron Wildavsky Dissertation Award

For the best dissertation on religion and politics successfully defended in 2010 and 2011

Award Committee: Elizabeth Shakman Hurd, Northwestern University (Chair); Michaelle L. Browers, Wake Forest University; Andrew F. March, Yale University; Elora Shehabuddin, Rice University Recipient: Toby Matthiesen, University of Cambridge

Title: "The Shia of Saudi Arabia: Identity Politics, Sectarianism and the Saudi State" 
(University of London, SOAS)

\section{Paul J. Weber Best Paper Award}

For the best paper dealing with religion and politics presented at the 2011 APSA Annual Meeting

Award Committee: Andrew C. Gould, University of Notre Dame (Chair); Sener Akturk, Koc University; Brandon T. Kendhammer, Ohio University

Recipient: Ramazan Kilinc, University of Nebraska-Omaha

Title: "Opportunity Junctures as Catalysts: Islam, Secularism and Democratic Consolidation in Turkey"

SECTION 15. SCIENCE, TECHNOLOGY AND ENVIRONMENTAL POLITICS

Don K. Price Award

For the best book in science and technology politics published in the past 3 years Award Committee: Roger B. Handberg, University of Central Florida; Ann C. Keller, University of California, Berkeley; Eric Lindquist, Boise State University

Recipients: Michael B. Berkman, Pennsylvania State University; Eric Plutzer, Pennsylvania State University

Title: Evolution, Creationism, and the Battle to Control America's Classrooms

\section{Lynton K. Caldwell Award}

For the best book in environmental politics published in the past 3 years

Award Committee: Dorothy Daley, University of Kansas; George Hoberg, University of British Columbia; David M. Shafie, Chapman University

Recipients: Troy D. Abel, Western Washington University; Michael E. Kraft, University of Wisconsin, Green Bay; Mark C. Stephan, Washington State University, Vancouver

Title: Coming Clean: Information Disclosure and Environmental Performance (2011), MIT Press

\section{Virginia M. Walsh Dissertation Award}

For the best dissertations in science, technology, and environmental politics

Award Committee: Sarah Anderson, University of California, Santa Barbara; Jessica F. Green, Case Western Reserve University; Pamela Stricker, California State University, San Marcos

Co-recipient: Kemi Fuentes-George, Middlebury College

Title: "Scientific Knowledge, Epistemic Communities and Environmental Policy in the Developing World" (University of
Massachusetts, Amherst) Co-recipient: Jennifer Hadden, University of Maryland

Title: "Contesting Climate Change: Civil Society Networks and Collective Action in the European Union" (Cornell University)

SECTION 16. WOMEN AND POLITICS RESEARCH

\section{Best Dissertation Award}

For the best dissertations on women and politics completed and successfully defended in the previous calendar year

Recipient: Jennifer Marie Piscopo, Salem College

Title: "Do Women Represent Women? Gender and Policy in Argentina and Mexico" (University of California, San Diego)

\section{Best Paper Award}

For the best paper presented at the 2011 APSA Annual Meeting on women and politics

Recipient: Eleonora Lepinard, University of Montreal

Title: "Doing Intersectionality: Varieties of Feminist Practices in France and Canada"

\section{Okin-Young Award}

The Okin-Young Award in Feminist Political Theory is co-sponsored by Women and Politics, Foundations of Political Theory, and the Women's Caucus for Political Science. This annual award recognizes the best paper on feminist political theory published in an English language journal during the previous academic year.

Award Committee: Claire E. Rasmussen, University of Delaware (Chair)

Recipient: Bonnie Honig, Northwestern University

Title: "Ismene's Forced Choice: Sacrifice and Sorority in Sophocles' Antigone" (Arethusa 44(1): 29-68)

\section{SECTION 17. FOUNDATIONS OF POLITICAL THOUGHT \\ Best Paper Award}

For the best paper presented on a foundation panel at the 2011 APSA Annual Meeting

Award Committee: Susan McWilliams, Pomona College (Chair); Roger Berkowitz, Bard College; Tamara Metz, Reed College Recipient: Jane A. Gordon, Temple University

Title: "Theorizing Contemporary Practices of Slavery"

\section{David Easton Award}

For a book that broadens the horizons of contemporary political science by engaging issues of philosophical significance in political life through any of a variety of approaches in the social sciences and humanities

Award Committee: Mark Reinhardt, Williams College (Chair); Jennifer Ring, University of Nevada, Reno; George M. Shulman, New York University

Co-recipient: Wendy Brown, University of California, Berkeley

Title: Walled States, Waning Sovereignty, Zone Books

Co-recipient: Bonnie Honig, Northwestern University

Title: Emergency Politics: Paradox, Law, Democracy, Princeton University Press

\section{First Book Award}

For the best first book published by a scholar in the early stages of his or her career in the area of political theory or political philosophy

Award Committee: Judith Grant, Ohio University (Chair); Chad Lavin, Virginia Tech; Bradley J. Macdonald, Colorado State University

Recipient: Stephen H. Marshall, University of Texas, Austin

Title: The City on the Hill from Below: The Crisis of Prophetic Black Politics, Temple University Press

\section{SECTION 18. INFORMATION TECH- NOLOGY AND POLITICS \\ Best Book Award}

Recognizes the best book in the area of information technology and politics published in the previous calendar year Award Committee: Philip N. Howard, University of Washington

Recipient: J. P. Singh, Georgetown University

Title: Globalized Arts: The Entertainment Economy and Cultural Identity, Columbia University Press

\section{Best Dissertation Award}

Recognizes the best dissertation in the area of information technology and politics Recipient: Daniel Ross, York University Title: "The Political Economy of Free and Open Source Software" (York University)

\section{Best Research Software Award}

Recognizes the website or software, which contributes to research and/or teaching in political science

Award Committee:Bob Boynton, University of Iowa 
Co-recipients: Micah Altman, Massachusetts Institute of Technology; Michael P. McDonald, George Mason University Title: DistrictBuilder

Co-recipient: Derrick L. Cogburn, American University and the Institute on Disability and Public Policy

Title: IDPP Cyberinfrastructure

\section{Best Graduate Student Paper Award} Recognizes the best sole-authored conference paper written by a political science graduate student working in the area of information technology and politics Award Committee: Kevin Jay Wallsten, California State University, Long Beach Recipients: Sean Goggins, Drexel University; Christopher Michael Mascaro, Drexel University; Alison Novak, Drexel University

Title: "The Daily Brew: The Structural Evolution of the Coffee Party on Facebook during the 2010 United States Midterm Election Season"

\section{SECTION 20. COMPARATIVE POLITICS}

Lijphart/Przeworski/Verba Data Set Award

For a publicly available data set that has made an important contribution to the field of comparative politics

Award Committee: John Gerring, Boston University; Karen Long Jusko, Stanford University; Peter N. Wallensteen, Uppsala University

Recipients: David Backer, University of Maryland; Daniele Caramani, University of St Gallen; Allen D. Hicken, University of Michigan, Ann Arbor; Kenneth W. Kollman, University of Michigan, Ann Arbor Title: Constituency-Level Elections Archive (CLEA)

\section{Leubbert Best Article Award}

For the best article in the field of comparative politics published in 2010 or 2011 Award Committee: Johanna Kristin Birnir, University of Maryland; Stathis N. Kalyvas, Yale University; Sara Watson, Ohio State University

Recipient: Philip Roessler, Duke University Title: "The Enemy Within. Personal Rule, Coups, and Civil War in Africa" (World Politics, 63(2))

\section{Leubbert Best Book Award}

For the best book in the field of comparative politics published in 2010 or 2011 Award Committee: Teri L. Caraway, Uni- versity of Minnesota; Ruth Berins Collier, University of California, Berkeley; Alexander Michael Hicks, Emory University Co-recipient: Alan M. Jacobs, University of British Columbia

Title: Governing for the Long Terms: Democracy and the Politics of Investment (2011), Cambridge University Press

Co-recipient: Jeffrey Winters, Northwestern University

Title: Oligarchy (2011), Cambridge University Press

\section{Powell Graduate Mentoring Award}

Awarded on a bi-annual basis to a political scientist who throughout his or her career has demonstrated a particularly outstanding commitment to the mentoring of graduate students in comparative politics Award Committee: Nancy Bermeo, Oxford University; Georg Vanberg, University of North Carolina, Chapel Hill; Victor C. Shih, Northwestern University

Recipient: David Collier, University of California, Berkeley

\section{Sage Best Paper Award}

For the best paper in the field of comparative politics presented at the 2011 APSA Annual Meeting

Award Committee: Leonardo R. Arriola, University of California, Berkeley; Giovanni Capoccia, Oxford University; Nita Rudra, University of Pittsburgh

Recipient: Rebecca Weitz-Shapiro, Brown University

Title: "What Wins Votes: Why Some Politicians Opt Out of Clientelism"

\section{SECTION 21. EUROPEAN POLITICS \\ AND SOCIETY}

\section{Best Book Award}

For the best book on European politics and society published in 2011

Award Committee: Giovanni Capoccia, Oxford University (Chair); Rafaela Dancygier, Princeton University; Nicolas Jabko, Johns Hopkins University

Recipient: David Stasavage, New York University

Title: States of Credit: Size, Power, and the Development of European Politics, Princeton University Press

\section{Ernst B. Haas Best Dissertation Award}

For the best dissertation on European politics and society filed in 2011

Award Committee: David Art, Tufts University (Chair); Deborah A. Boucoyannis, Uni- versity of Virginia; Monika Nalepa, Princeton University

Recipient: Jordan Luc Gans-Morse, Northwestern University

Title: "Building Property Rights: Capitalists and the Demand for Law in Post-Soviet Russia" (University of California, Berkeley)

\section{Best Paper Award}

Given for the best paper on European politics and society presented at the 2011 APSA Annual Meeting

Award Committee:Donna Bahry, Pennsylvania State University (Chair); Willem Maas, York University; Ben William Ansell, University of Minnesota, Twin Cities

Recipients: Christilla Roederer-Rynning, Syddansk Universitet; Frank Schimmelfennig, Swiss Federal Institute of Technology Zurich

Title: "Bringing Co-Decision to Agriculture: A Hard Case of Parliamentarization"

SECTION 23. POLITICAL

COMMUNICATION

Timothy Cook Best Graduate Student Paper Award

For the best paper on political communication presented by a graduate student at the 2011 APSA Annual Meeting

Award Committee: Stephanie Burkhalter, Humboldt State University (Chair); Johanna Dunaway, Louisiana State University; C. Danielle Vinson, Furman University

Recipients: James N. Druckman, Northwestern University; Thomas J. Leeper, Northwestern University

Title: "Learning More from Political Communication Experiments: The Importance of Pretreatment Effects"

\section{David Swanson Career Achievement}

For lifetime service to the study of political communication

Award Committee: Gienpietro Mazzoleni, Università di Milano (Chair); Christina Holtz-Bacha, University of ErlangenNuernberg; Ann N. Crigler, University of Southern California; Kathleen Hall Jamieson, University of Pennsylvania

Recipient: David L. Paletz, Duke University

\section{Doris Graber Award}

For the best book of the year published on political communication within the last 10 years

Award Committee: Roderick Hart, University of Texas Austin (Chair); Steven Livingston, George Washington University; Ted Brader, University of Michigan 
Recipients: Robert Huckfeldt, University of California, Davis; Paul Johnson, University of California, Davis; John D. Sprague, Washington University

Title: Political Disagreement: The Survival of Diverse Opinions within Communication Networks (2004), Cambridge University Press

\section{Paul Lazarsfeld Best Paper Award}

For the best paper on political communication presented at the 2011 APSA Annual Meeting

Award Committee: Kimberly A. Gross, George Washington University (Chair); Craig Leonard Brians, Virginia Tech; Sean Richey, George State University

Recipients: Christopher F. Karpowitz, Brigham Young University; Tali Mendelberg, Princeton University

Title: "Do Women Deliberate with a Distinctive Voice? How Decision Rules and Group Gender Composition Affect the Content of Deliberation"

\section{SECTION 24. POLITICS AND HISTORY}

\section{J. David Greenstone Book Prize}

For the best book in politics and history published in 2010 or 2011

Award Committee: Thomas M. Keck, Syracuse University (Chair); Amel F. Ahmed, University of Massachusetts, Amherst; Colin Moore, University of Hawaii, Manoa Recipient: Julian Go, Boston University Title: Patterns of Empire: The British and American Empires, 1688 to Present (2011), Cambridge University Press

\section{Mary Parker Follett}

For the best article or chapter in politics and history published in 2010 or 2011 Award Committee: Alan M. Jacobs, University of British Columbia (Chair); Devin Caughey, University of California, Berkeley; Daniel Galvin, Northwestern University; Catherine Paden, Simmons College Recipients: Diana Dumitru, Moldova State Pedagogical University; Carter R. Johnson, American Councils, Moscow

Title: "Constructing Interethnic Conflict and Cooperation: Why Some People Harmed Jews and Others Helped Them During the Holocaust in Romania" (World Politics 63, January 2011, 1-42)

\section{Walter Dean Burnham Dissertation Award}

For the best dissertation in the field of politics and history
Award Committee: Catherine Boone, University of Texas, Austin (Chair); Beth A. Rosenson, University of Florida; James Shoch, California State University, Sacramento

Recipient: Gwendoline M. Alphonso, Fairfield University

Title: "Hearth and Soul: Political Parties, Family Ideologies, and the Development of Social Policy in the 2oth Century" (Cornell University)

\section{SECTION 25. POLITICAL ECONOMY Fiona McGillivray Prize Best Paper Award}

For the best paper in Political Economy presented at the 2011 APSA Annual Meeting

Award Committee: Margarita Estevez-Abe, Syracuse University (Chair); William Roberts Clark, University of Michigan; Barbara F. Walter, University of California, San Diego

Recipients: Benjamin S. Barber, IV, Duke University; Pablo Beramendi, Duke University; Erik M. Wibbels, Duke University Title: "The Behavioral Foundations of Social Politics: Evidence from Surveys and a Laboratory Democracy"

\section{Michael Wallerstein Award}

For the best published article in Political Economy in the previous calendar year Award Committee: Beatriz Magaloni, Stanford University (Chair); Jens Hainmueller, Massachusetts Institute of Technology; Edward D. Mansfield, University of Pennsylvania

Recipients: Kenneth F. Scheve, Stanford University; David Stasavage, New York University

Title: "The Conscription of Wealth: Mass Warfare and the Demand for Progressive Taxation," International Organization 64(4) Honorable Mention: Yotam Margalit, Columbia University

Title: "Costly Jobs: Trade-related Layoffs, Government Compensation, and Voting in U.S. Elections." American Political Science Review 105(1):169-88

\section{Mancur Olson Best Dissertation Award}

For the best dissertation completed and accepted in the previous 2 years

Award Committee: Catherine Hafer, New York University (Chair); John Stephen Ahlquist, University of Wisconsin, Madison; Stephen B. Kaplan, George Washington University
Recipient: Xiaobo Lu, Texas A\&M University

Title: "The Political Causes and Consequences of Inequality of Opportunity" (Yale University)

\section{William H. Riker Book Award}

For the best book on political economy published in the past 3 years

Award Committee: Carles Boix, Princeton University (Chair); Ben William Ansell, University of Minnesota, Twin Cities; Jenna Bednar, University of Michigan Recipient: Tom Clark, Emory University Title: The Limits of Judicial Independence (2011), Cambridge University Press Honorable Mention: Jonathan Bendor, Stanford University; Daniel Diermeier, Northwestern University; David A. Siegel, Florida State University; Michael M. Ting, Columbia University

Title: A Behavioral Theory of Elections

Honorable Mention: David Stasavage, New York University

Title: States of Credit: Size, Power, and the Development of European Polities

\section{SECTION 27. NEW POLITICAL SCIENCE}

\section{Christian Bay Award}

For the best paper presented at a New Political Science panel at the 2011 APSA Annual Meeting

Award Committee: Elisabeth K. Chaves, Virginia Polytechnic Institute and State University (Chair); William L. Niemi, Western State College of Colorado; Stephen Pimpare, City University of New York

Recipient: Michael David Forrest, University of Minnesota

Title: "The Limits of Political Representation: Anti-Foreclosure Activism and Racial Injustice in the Post-Civil Rights Era"

\section{Richard Cloward and Frances Fox Piven Award}

For an active group, in the region of the annual meeting, that puts the ideals of the New Political Science Section, "to make the study of politics relevant to the struggle for a better world," into practice

Award Committee: Michael Forman, University of Washington, Tacoma (Chair); Michael J. Bosia, St. Michael's College; Margaret Groarke, Manhattan College; Frances Fox Piven, CUNY Graduate Center Recipient: New Orleans Workers' Center for Racial Justice 
Charles A. McCoy Career Achievement Award

For a progressive political scientist who has had a long, successful career as a writer,

Teacher, and activist

Award Committee: Manfred B. Steger, University of Hawaii, Manoa (Chair); Christine A. Kelly, William Paterson University; Katherine Young, University of Hawaii, Hilo

Recipient: Sanford F. Schram, Bryn Mawr College

\section{Michael Harrington Book Award}

For an outstanding book that demonstrates how scholarship can be used in the struggle for a better world

Award Committee: Bradley J. Macdonald, Colorado State University (Chair); Sean Parson, University of Alaska, Fairbanks Recipients: Richard C. Fording, University of Alabama, Tuscaloosa; Sanford F. Schram, Bryn Mawr College; Joe Soss, University of Minnesota

Title: Disciplining the Poor: Neoliberal Paternalism and the Persistent Power of Race, University of Chicago Press

\section{SECTION 28. POLITICAL}

\section{PSYCHOLOGY}

\section{Best Dissertation Award}

For the best dissertation in political psychology filed during the previous year Award Committee: Pete Hatemi, Pennsylvania State University (Chair); J. Tobin Grant, Southern Illinois University at Carbondale; Elizabeth Zechmeister, Vanderbilt University

Recipient: Christopher T. Dawes, New York University

Title: "An Examination of Potential Causal Mechanisms Linking Genes and Political Behavior" (University of California, San Diego)

Honorable Mention: Sarah Harrison, London School of Economics and Political Science

Title: "Ideological (Mis)Match? Mapping Extreme Right Ideological Discourse and Voter Preferences"

\section{Robert Lane Best Book Award}

For the best book in political psychology published during the previous year Award Committee: Mark Peffley, University of Kentucky (Chair); Jon Hurwitz, University of Pittsburgh; Jennifer Jerit, Florida State University

Co-recipients: James N. Druckman, Northwestern University; Donald P. Green,
Columbia University; James H. Kuklinski, University of Illinois at Urbana-Champaign; Arthur Lupia, University of Michigan, Ann Arbor

Title: Cambridge Handbook of Experimental Political Science, Cambridge University Press

Co-recipient: Deborah Schildkraut, Tufts University

Title: Americanism in the Twenty-First Century, Cambridge University Press

\section{Best Paper Award}

For the best paper in political psychology delivered at the 2011 Annual Meeting Award Committee: Michael E. Morrell, University of Connecticut (Chair); Joanne Miller, University of Minnesota; David W. Nickerson, University of Notre Dame Recipients: Christopher F. Karpowitz, Brigham Young University; Tali Mendelberg, Princeton University

Title: "Do Women Deliberate with a Distinctive Voice? How Decision Rules and Group Gender Composition Affect the Content of Deliberation"

\section{Distinguished Junior Scholars Award}

The APSA Political Psychology section gives up to nine $\$ 200$ grants, meant for travel to the APSA, for junior scholars (graduate students or those no more than 7 years since receiving their $\mathrm{PhD}$ )

Award Committee: Matt Levendusky, University of Pennsylvania (Chair); Kristen Monroe, University of California Irvine; Christopher Larimer University of Northern Iowa

Recipients:

Erica Czaja, Princeton University

Cengiz Erisen, TOBB University of Economics and Technology

Kristyn Karl, University of Michigan, Ann Arbor

Mona S. Kleinberg, Rutgers University

Ashley Muddiman, University of Texas, Austin

Spencer Piston, University of Michigan, Ann Arbor

Jaime E. Settle, College of William \& Mary Rachel Anne Silbermann, Yale University April Strickland, SUNY, Stony Brook University

Juan Luis Urbano, Jr., University of Kansas

SECTION 29. POLITICAL SCIENCE EDUCATION

\section{Best Presentation Award}

For the best presentation on undergradu- ate education at the 2011 APSA Annual Meeting

Award Committee: Alison Rios Millett McCartney, Towson University (Chair)

Recipient: Rebecca Glazier, University of Arkansas, Little Rock

Title: "Satire and Efficacy in the Political Science Classroom"

SECTION 32. ELECTIONS, PUBLIC OPINION, AND VOTING BEHAVIOR

\section{Best Paper Award}

For the best paper delivered at the 2011 APSA Annual Meeting

Award Committee: Walter J. Stone, University of California, Davis (Chair); André Blais, Université de Montréal; Zoe M. Oxley, Union College

Recipients: James N. Druckman, Northwestern University; Thomas J. Leeper, Northwestern University; Jordan Fein, Northwestern University

Title: "Framing and Biased Information Search"

\section{Emerging Scholar Award}

Recognizes the top scholar in the field who is within 10 years of her or his $\mathrm{PhD}$

Award Committee: David P. Redlawsk, Rutgers University (Chair); Andrea Louise Campbell, Massachusetts Institute of Technology; Karen M. Kaufmann, University of Maryland

Recipient: Kevin Arceneaux, Temple University

\section{Philip E. Converse Best Book Award}

For an outstanding book in the field published at least 5 years ago

Award Committee: Christopher Wlezien, Temple University (Chair); Sunshine Hillygus, Duke University; Tia Stokes-Brown, Bucknell University

Recipients: Edward G. Carmines, Indiana University, Bloomington; James A. Stimson, University of North Carolina, Chapel Hill

Title: Issue Evolution: Race and the Transformation of American Politics (1989), Princeton University Press

\section{Warren E. Miller Award}

Awarded every 2 or 3 years for an outstanding career of intellectual accomplishment and service to the profession in elections, public opinion, and voting behavior Award Committee: Elizabeth TheissMorse, University of Nebraska, Lincoln (Chair); Michael D. Martinez, University of Florida; Daniel Rubenson, Ryerson Uni- 
versity

Recipient: Donald R. Kinder, University of

Michigan, Ann Arbor

\section{SECTION 33. RACE, ETHNICITY AND POLITICS}

\section{Best Dissertation Award}

For the best dissertation completed January 2011 to December 2011 on race, ethnicity, and politics

Award Committee: Christopher S. Parker, University of Washington (Chair); Regina Freer, Occidental College; John H. Mollenkopf, CUNY Graduate Center

Recipient: Chris Zepeda-Millan, University of Chicago

Title: "Dignity's Revolt: Threat, Identity, and Immigrant Mass Mobilization" (Cornell University)

\section{SECTION 34. INTERNATIONAL} HISTORY AND POLITICS

\section{Jervis and Schroeder Best Book} Award

For the best book on international history and politics published in the previous calendar year

Award Committee: Colin Elman, Syracuse University (Chair)

Recipient: Elizabeth Nathan Saunders, George Washington University

Title: Leaders at War: How Presidents Shape Military Interventions, Cornell University Press

\section{SECTION 35. COMPARATIVE}

\section{DEMOCRATIZATION}

\section{Best Book Award}

For the best book in the field of comparative democratization published in 2011 (authored, co-authored, or edited)

Award Committee: Thad Dunning, Yale University; Michael L. Ross, University of California, Los Angeles; Benjamin Smith, University of Florida

Recipient: Susan Dayton Hyde, Yale University

Title: The Pseudo-Democrat's Dilemma: Why Election Monitoring Became an International Norm, Cornell University Press Honorable Mention: Vineeta Yadav, Pennsylvania State University

Title: Political Parties, Business Groups, and Corruption in Developing Countries, Oxford University Press

\section{Best Field Research Award}

Rewards dissertation students who conduct especially innovative and difficult fieldwork
Award Committee: Kenneth F. Greene, University of Texas, Austin (Chair); Claire Leslie Adida, University of California, San Diego; Lily L. Tsai, Massachusetts Institute of Technology

Recipient: Simon Chauchard, Dartmouth College

Title: "From Political Power To Changing Group Relations? Tracking the Psychological Impact of Political Inclusion in Rura India"

Honorable Mention: James Long, University of California, San Diego

Title: "Ethnic Voting in Kenya and Ghana and Election Fraud in Uganda and Afghanistan"

\section{Best Paper Award}

Recognizes the best paper presented on a human rights section panel at the 2011 APSA Annual Meeting

Award Committee: Marc Morjé Howard, Georgetown University (Chair); Lisa A. Blaydes, Stanford University; Christian Houle, Trinity College

Recipient: Susan C. Stokes, Yale University

Title: "What Killed Vote Buying in Britain?"

\section{Juan Linz Best Dissertation Award}

For the best dissertation in the comparative study of democracy completed and accepted in the past 2 calendar years Award Committee: Nancy Bermeo, Oxford University (Chair); Pauline Jones Luong, University of Michigan, Ann Arbor; Thomas Pepinsky, Cornell University

Recipient: Noam Lupu, Juan March Institute

Title: "Party Brands in Crisis: Partisanship, Brand Dilution and the Breakdown of Political Parties in Latin America" (Princeton University)

\section{SECTION 36. HUMAN RIGHTS \\ Best Book Award}

For the best single-authored, multiauthored, or edited volume on human rights published in the previous year Award Committee: Mahmood Monshipouri, San Francisco State University (Chair); Zehra F. Kabasakal Arat, State University of New York, Purchase; Bethany Barratt, Roosevelt University Recipient: Susan Stokes, Yale University Title: What Killed Vote Buying in Britain and the United States?
SECTION 37. QUALITATIVE

METHODS

David Collier Mid-Career Achievement Award

Given to a mid-career political scientist to recognize distinction in methodological publications, innovative application of qualitative and multi-method approaches in substantive research, and/or institutional contributions to this area of methodology Award Committee: Gary Goertz, University of Arizona (Chair); Dan Carpenter, Harvard University; Rose McDermott, Brown University

Recipient: Colin Elman, Syracuse University

\section{Giovanni Sartori Book Award}

Granted to a single-authored or multiauthored book, or to an edited volume published in the previous calendar year Award Committee: Lauren Morris MacLean, Indiana University, (Chair); Evan Lieberman, Princeton University; and Timothy Crawford, Boston College

Recipient: Alan M. Jacobs, University of British Columbia

Title: Governing for the Long Term: Democracy and the Politics of Investment, Cambridge University Press

\section{Alexander George Article/Book Chap- ter Award}

Granted to the author of a journal article or a chapter in an edited volume that stands on its own as an article

Award Committee: Melani Cammett Brown University (Chair); Hillel Soifer, Temple University; Gerardo Munck, University of Southern California

Recipient: Anna Grzymala-Busse, University of Michigan

Title: "Time Will Tell: Temporality and the Analysis of Causal Mechanisms and Processes" (Comparative Political Studies, Volume 44, September 2011).

\section{APSR Submission Award}

For the best qualitative manuscript submitted to the American Political Science Review in the previous calendar year Recipient: Jeremy M. Menchik, Boston University

Title: "The Origins of Intolerance in Islamic Institutions"

Recipient: Paul Staniland, University of Chicago

Title: "States, Insurgents, and Wartime Political Orders" 


\section{Sage Paper Award}

For the best paper presented at the 2011 APSA Annual Meeting

Award Committee: Jennifer Hadden, University of Maryland; Jonathan GithensMazer, University of Exeter; Erica Townsend-Bell, University of Iowa

Recipients: Derek Beach, University of Aarhus; Rasmus Brun Pedersen, University of Aarhus

Title: "What is Process Tracing Actually Tracing? The Three Variants of Process Tracing Methods and Their Uses and Limitations"

\section{SECTION 38. SEXUALITY AND POLITICS}

\section{Best Conference Paper Award}

For the best paper exploring sexuality and politics presented at the 2011 APSA Annual Meeting Award Committee: Ella Myers, University of Utah (Chair); Beth Kiyoko Jamieson, The Fund for New Jersey; Christine Keating, Ohio State University

Recipients: Abouzar Nasirzadeh, University of Toronto; Kate Korycki, University of Toronto

Title: "Desire Re-Cast: The Production of Gay Identity in Iran"

\section{SECTION 40. CANADIAN POLITICS}

\section{Mildred Schwartz Lifetime}

\section{Achievement}

Recognizes scholarship and leadership in bringing the study of Canadian politics to the international political science community

Award Committee: Fred E. Cutler, University of British Columbia; Elisabeth L.
Gidengil, McGill University; Michael D. Martinez, University of Florida; David Rayside, University of Toronto; Mildred A. Schwartz, New York University Recipient: Peter H. Russell, University of Toronto

\section{Seymour Martin Lipset Best Book Award}

To honor a significant contemporary contribution to the scholarship on Canadian politics, or Canada in a comparative perspective, or a comparative analysis of Canada with other countries, particularly the United States

Award Committee: Cristine de Clercy, University of Western Ontario; Katherine Fierlbeck, Dalhousie University; Kenneth M. Holland, Ball State University; Michael Lusztig, Southern Methodist University; Richard Vengroff, Kennesaw State University

Co-recipient: Janet Ajzenstat, McMaster University

Title: The Canadian Founding: John Locke and Parliament, McGill-Queen's University Press

Co-recipient: Stephen Clarkson, University of Toronto

Title: Does North America Exist? Governing the Continent After NAFTA and 9/11, University of Toronto Press

\section{SECTION 42. EXPERIMENTAL RESEARCH}

\section{Best Book Award}

For the best book published in 2011 that either uses or is about experimental research methods in the study of politics Award Committee: Melissa R. Michelson, Menlo College (Chair); Adam J. Berinsky, Massachusetts Institute of Technology; Thad Dunning, Yale University

Recipients: James N. Druckman, Northwestern University; Donald P. Green, Columbia University; James H. Kuklinski, University of Illinois at Urbana-Champaign; Arthur Lupia, University of Michigan, Ann Arbor

Title: Cambridge Handbook of Experimental Political Science, Cambridge University Press

\section{Best Paper Award}

For the best paper presented at the 2011 APSA Annual Meeting featuring experimental analyses

Award Committee: Daniel Rubenson, Ryerson University (Chair); C. Daniel Myers, University of Michigan; Christopher R. Weber, Louisiana State University Recipients: Jennifer Jerit, Florida State University; Jason Barabas, Florida State University; Scott Clifford, Florida State University

Title: "Comparing Treatment Effects in Parallel Experiments" 